\title{
Kajian Yuridis Pembiayaan Ijarah Perbankan Syari'ah Menurut Hukum Positif
}

\author{
Muhaimin $^{1}$ \\ Fakultas Hukum Universitas Mataram, \\ Jln. Majapahit No. 62 Mataram 83125, \\ Telp. (0370), 633035, Fax. 626954 \\ Email: mmuhaimin@gmail.com

\section{Sumiati $^{2}$} \\ Fakultas Hukum Universitas Mataram, \\ Jln. Majapahit No. 62 Mataram 83125, \\ Telp. (0370), 633035, Fax. 626954 \\ Email:sumiati@mail.com

\section{Budi Sutrisno $^{3}$} \\ Fakultas Hukum Universitas Mataram, \\ Jln. Majapahit No. 62 Mataram 83125, \\ Telp. (0370), 633035, Fax. 626954 \\ Email: budisutrisno@gmail.com
}

\begin{abstract}
ABSTRAK
Pengaturan usaha perbankan syariah di Indonesia mengalami perubahan yang pada awalnya hanya mengatur tentang usaha perbankan konvensional, kemudian berkembang juga untuk perbankan syariah sebagai bagian dari dual insurance system, namun dalam operasional perbankan syariah masih memiliki problematika terkait dengan pengaturan dalam pembiayaan ijarah. Hal ini berimplikasi terhadap legalitas akad pembiayaan ijarah di perbankan syari'ah menurut prespektif hukum positif. Tujuan penelitian ini adalah menganalisis permasalahan hukum pengaturan akad pembiayaan ijarah di perbankan syariah menurut hukum positif. Metode yang digunakan dalam penelitian ini adalah penelitian hukum normatif, dengan menggunakan bahan hukum primer, sekunder dan tersier tentang perbankan syari'ah yang dikumpulkan melalui studi dokumen dan kepustakaan, untuk kemudian dilakukan analisis secara deskriptif kualitatif untuk menghasilkan kesimpulan secara deduktif. Hasil Penelitian ini, Pertama, Permasalahan hukum pengaturan akad pembiayaan ijarah pada perbankan
\end{abstract}

3 Dosen Fakultas Hukum Universitas Mataram. 
syariah menurut hukum positif adalah pengaturan akad pembiayaan ijarah belum diatur secara detail sehingga belum dipahami oleh pengelola dan nasabah perbankan syariah. Kedua, Model akad ijarah di perbankan syariah menurut prespektif hukum positif adalah model akad pembiayaan dan pelayanan jasa diantaranya akad pembiayaan sewa menyewa, sewa beli dengan opsi peralihan kepemilikan (ijarah muntahiyah bittamlik), dan akad pembiayaan multijasa, dan akad pelayanan jasa seperti jasa save deposit box. Rekomendasi penelitian ini; Pemerintah perlu segera menerbitkan peraturan pelaksanaan terhadap Undang-Undang Nomor 21 Tahun 2008 tentang Perbankan Syariah khususnya yang berkaitan dengan akad ijarah, dan Majelis Ulama dan para ahli Hukum Islam perlu segera menyusun panduan akad ijarah sebagai pedoman bagi perbankan syari'ah dalam operasionalnya.

Kata Kunci : Pembiayaan, Ijarah, Perbankan Syariah.

\section{ABSTRACT}

\section{A. PENDAHULUAN}

Indonesia telah menjalankan sistem hukum perbankan yang menggunakan dual banking system, yaitu bank konvensional dan bank syari'ah. Penerapan dua sistem perbankan ini telah diakui dan diterapkan secara bersamaan baik secara defakto maupun dejure sejak tahun 1998 berdasarkan Undang-Undang Nomor 10 Tahun 1998 dan dipertegas kembali oleh Undang-Undang Nomor 21 Tahun 2008 tentang Perbankan Syariah.

Hukum harus mampu memberikan perlindungan dan kepastian hukum bukan hanya terhadap perbankan konvensional tetapi juga perbankan syari'ah diatur secara jelas dalam hukum positif di Indonesia, sehingga memiliki kedudukan yang sama sebagai bagian dari sistem hukum perbankan nasional. Namun demikian masih banyak permasalahan yang dapat berimplikasi secara hukum terhadap keberadaan bisnis perbankan syari'ah dalam menjalankan bisnisnya secara bersamaan dengan perbankan konvensional, khususnya tentang akad pembiayaan ijarah.

Mengingat masih belum jelasnya pengaturan yang terkait dengan akad pembiayaan ijarah di perbankan syariah, maka dipandang perlu adanya suatu pemikiran dan pengkajian tentang kejelasan pengaturan akad pembiayaan ijarah pada perbankan syariah, dengan harapan dalam pelaksanaannya dapat sejalan dengan hukum positif. Penelitian ini akan menawarkan kajian sebagai bahan pemikiran untuk mengidentifikasi pengaturan akad pembiayaan ijarah pada perbankan syariah dan model akad ijarah di perbankan syariah menurut prespektif hukum positif.

Kejelasan pengaturan atas setiap bisnis menjadi dasar dan indikator tegaknya negara hukum (rechstaats) dan terwujudnya kepastian hukum, karena keberadaan hukum menjadikan bisnis yang dijalankan berada dalam rambu dan norma hukum yang memastikan hak dan kewajiban masyarakat terlindungi oleh negara, dan akan mencegah terjadinya hukum rimba. Dengan adanya hukum yang adil akan menjadikan posisi para pihak menjadi seimbang dan setara dalam hukum, demikian halnya dengan bisnis yang dijalankan berada dalam koridor hukum dan tidak dilakukan secara illegal. Dengan demikian, penelitian ini penting dilakukan dengan tujuan khusus untuk mengkaji tentang pengaturan akad pembiayaan ijarah pada perbankan syari'ah menurut hukum positif.

Penelitian ini penting untuk dilakukan dengan harapan hasil yang ingin dicapai dalam penelitian ini adalah mampu menghasilkan analisis yang mendalam dan komprehensif tentang pengaturan akad pembiayaan ijarah pada perbankan syari'ah 
menurut hukum positif..

\section{B. METODE PENELITIAN}

\section{Pendekatan}

Penelitian ini mendasarkan pada penelitian hukum yang dilakukan dengan pendekatan doktrinal atau normatif ${ }^{l}$ yang memandang hukum sebagai seperangkat aturan atau kaidah yang bersifat normatif yaitu yang memandang hukum sebagai seperangkat kaidah yang bersifat normatif atau apa yang menjadi teks Peraturan Perundang-Undangan (law in books). Berdasarkan hal tersebut, maka dalam penelitian ini pendekatan yang digunakan yakni pendekatan perundang-undangan (statute approach), pendekatan konseptual dan (conceptual approach $)^{2}$.

\section{Sumber Dan Jenis Bahan Hukum}

Penelitian ini dilaksanakan di

Perpustakaan baik perpustakaan umum maupun perpustakaan Universitas Mataram, Perpustakaan Fakultas Hukum, serta perpustakaan yang tersedia secara digital/online melalui media internet. Penelitian ini menggunakan data sekunder, yaitu data-data yang berasal dari bahanbahan pustaka atau bahan hukum baik bahan hukum primer, bahan hukum sekunder dan bahan hukum tersier, yang meliputi: al-Qur'an, al-Hadits, ijtihad ulama, dokumen-dokumen tertulis, yang bersumber dari peraturan perundangundangan (hukum positif di Indonesia), literatur dan sumber hukum dalam Islam, Fatwa Dewan Syari'ah Nasional MUI, hasil-hasil penelitian, artikel-artikel ilmiah, buku-buku literatur, dokumen-dokumen resmi, dan lain-lain serta kamus maupun ensiklopedi yang diperlukan yaitu yang berkaitan dengan perbankan syari'ah.

\section{Pengumpulan Bahan Hukum}

Data yang diperlukan dalam penelitian ini, akan dikumpulkan melalui studi kepustakaan (liabrary research) atau studi dokumen yang dilakukan dengan tahapan sebagai berikut: studi kepustakaan dan dokumen yang dilakukan dengan cara menginventarisir peraturan perundangundangan, buku-buku dan literatur lain sebagai sumber data sekunder yang berkaitan dengan fokus penelitian, kemudian dilakukan klasifikasi untuk kemudian dilakukan validasi, untuk membangun argumentasi hukum.

\section{Analisa Bahan Hukum.}

Sesuai dengan metode pendekatan yang digunakan, maka dalam penelitian ini analisis yang digunakan mendasarkan pada pendekatan doktrinal yaitu dilakukan analisis dengan menggunakan metode analisis kualitatif melalui metode interpretasi hukum diantaranya metode interpretasi otentik, dan gramatikal untuk membangun argumentasi hukum, sehingga dapat ditarik kesimpulan secara deduktif.

\section{PEMBAHASAN}

\section{A. Pengaturan Akad Pembiayaan Ijarah pada Perbankan Syariah menurut Hukum Positif}

\section{Landasan Hukum Ijarah}

Landasan hukum tentang Ijarah diantaranya terdapat dalam Al-qur'an dan Hadits antara lain:

Dalam Firman Allah SWT:

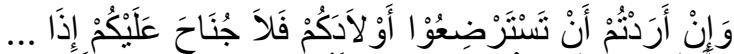

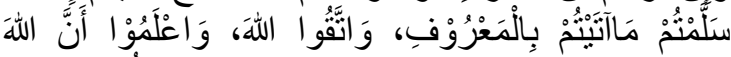

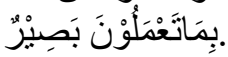

“...Dan jika kamu ingin anakmu disusukan oleh orang lain, tidak dosa bagimu apabila kamu memberikan pembayaran menurut yang patut.

2 Peter Mahmud Marzuki, Penelitian Hukum, Kencana Jakarta, 2004 hal 20 
Bertaqwalah kepada Allah; dan ketahuilah bahwa Allah Maha Melihat apa yang kamu kerjakan." \{QS. Al-Bâqarah [2]: 233\}

Firman Allah SWT :

"Apakah mereka yang membagibagikan rahmat Tuhanmu? Kami telah menentukan antara mereka penghidupan mereka dalam kehidupan dunia, dan Kami telah meninggikan sebagian mereka atas sebagian yang lain beberapa derajat, agar seba-gian mereka dapat mempergunakan sebagian yang lain. Dan rahmat Tuhanmu lebih baik dari apa yang mereka kumpulkan." \{QS. al-Zukhruf [43]: 32\}

"Salah seorang dari kedua wanita itu berkata: Hai ayahku, ambilah ia sebagai orang yang bekerja pada (kita), karena sesungguhnya orang yang paling baik yang kamu ambil untuk bekerja (pada kita) adalah orang yang kuat lagi dapat dipercaya" (QS. al-Qashash [28]:26).

Dan terdapat dalam Hadits sebagai berikut:

"Sesungguhnya Rasulullah saw pernah berbekam kepada seseorang dan beliau memberi upah tukang bekam itu (HR. Bukhari-Muslim).

"Berikanlah upah kepada orang yang kamu pekerjakan sebelum kering keringat mereka”. (HR. Abu Ya'la, Ibnu Majah, at-Thabrani dan Tirmidzi) ${ }^{3}$.

"Dari Abu Hurairah bahwa Rasulullah saw bersabda: Apabila kamu mengangkat pekerja maka beritahukanlah upahnya". (HR. Abdur Razaq).

"Dari Sa'd bin Abi Waqqash, di berkata: Kami pernah menyewakan tanah pada masa Rasulullah saw dengan (bayaran) hasil pertaniannya, maka Rasulullah saw melarang kami melakukan hal tersebut dan mengizinkan kami menyewakannya dengan emas atau perak". (HR. Al-Darimi).

"Dari Amr bin Auf dari ayahnya dari kakeknya bahwa Rasulullah saw bersabda: Perdamaian dapat dilakukan di

\footnotetext{
3 Burhanuddin Susanto, Hukum Perbankan Syariah di Indonesia (Yogyakarta:UII Press,Juni 2008), Hlm.273

4 Adiwarman Karim, Bank Islam "Analisis Fiqih dan
}

antara kaum muslimin kecuali perdamaian yang mengharamkan yang halal atau menghalalkan yang haram; dan kaum muslimin terikat dengan syarat-syarat mereka kecuali syarat yang mengharamkan yang halal atau menghalalkan yang haram”. (HR. Tirmidzi)

Ijma' ulama tentang kebolehan melakukan akad sewa menyewa. Selanjutnya Kaidah fiqh yang menjelaskan bahwa "Pada dasarnya semua bentuk muamalah boleh dilakukan kecuali ada dalil yang mengharamkannya." Kemudian "Menghindarkan mafsadat (kerusakan/bahaya) harus didahulukan atas mendatangkan kemaslahatan."

Menurut Fatwa Dewan Syariah Nasional Nomor: 09/DSN-MUI.IV/2000 tentang Pembiayaan Ijarah, bahwa ijarah adalah akad pemindahan hak guna (manfaat) atas suatu barang atau jasa dalam waktu tertentu melalui pembayaran sewa atau upah, tanpa diikuti dengan pemindahan kepemilikan barang itu sendiri ${ }^{4}$.

Ijarah didefinisikan sebagai hak untuk memanfaatkan barang atau jasa dengan membayar imbalan tertentu. Bank Syariah yang menerapkan produk ijarah, dapat melakukannya dalam bentuk leasing, akan tetapi pada umumnya, bank Syariah dalam prakteknya lebih banyak menggunakan ijarah muntahiya bit tamlik karena lebih memudahkan dalam operasional bank. Selain itu bank syariah tidak direpotkan untuk mengurus pemelihara asset baik pada saat leasing maupun sesudahnya ${ }^{5}$.

Sewa atau ijarah dapat dipakai sebagai bentuk pembiayaan, pada mulanya bukan merupakan bentuk pembiayaan. Tetapi merupakan aktifitas jual-beli. Individu yang membutuhkan pembiayaan untuk membeli asset, dapat mendatangi hak milik dana dalam hal ini (bank) untuk membiayai asset produktif. Pemilik dana

4 Muhaimin dkk | [Kajian Yuridis Pembiayaan...]

Keuangan ” (Jakarta: PT. Raja Grafindo Persada, maret 2010), HIm 138

${ }^{5}$ Adiwarman karim, Loc. Cit. 
kemudian membeli barang dimaksud dan kemudian menyewakannya kepada yang membutuhkan asset tersebut.

Bentuk pembiayaan ini merupakan salah satu tehnik pembiayaan ketika kebutuhan pembiayaan investor untuk membeli asset terpenuhi, dan investor hanya membayar sewa pemakaian tanpa harus mengeluarkan modal yang cukup besar untuk membeli asset tersebut.

\section{Permasalahan Pengaturan Ijarah}

Transaksi ijarah dilandasi adanya perpindahan manfaat (hak milik), jadi pada dasarnya prinsip ijarah sama saja dengan prinsip jual beli, pada jual beli objek transaksinya barang, pada ijarah objek transaksinya adalah barang maupun jasa ${ }^{6}$.

Dalam praktek perbankan syariah akad ijarah sulit dilaksanakan, karena akan membuat repot dan rumit dalam pelaksanaannya, oleh karena itu ijarah dalam prakteknya perbankan syariah menggunakan sistem pembiayaan (penyaluran) dana dan pelayanan jasa perbankan untuk pembiayaan yang lazim adalah pembiayaan dengan skema Ijarah muntahiyah bittamlik (IMBT atau sewa beli, pembiayaan multijasa (dimana bank syariah mendapatkan imbalan jasa atas pembiayaan yang diberikan kepada nasabah seperti Rumah, Mobil dan lain-lain. Dan skim pembiayaan ini menggunakan skim pembiayaan sewa menyewa hal ini sejalan dengan prinsip dasar muamalah yang mana bahwa "hukum asalnya muamalah pada dasarnya boleh kecuali ada dalil yang melarangnya". Dalam hal akad ijarah tidak ada dalil yang melarangnya artinya boleh termasuk pengembangannya menjadi akad IMBT atau akad sewa menyewa. Walaupun secara prinsip memungkinkan untuk pembiayaan infrastruktur dan peralatan,

\footnotetext{
6 Adiwarman Karim, Bank Islam "Analisis Fiqih dan Keuangan ” (Jakarta: PT. Raja Grafindo Persada, Maret 2010), Hlm 137

${ }^{7}$ Muhammad Syafi'i Antonio, Bank Syariah Dari Teori ke Praktek, (Jakarta: Gema Insani, 2001), 116
}

namun dalam praktek masih belum dapat dilaksanakan, karena bank masih mudah menggunakan skema murabahah (jual beli).

\section{B. Model Akad Ijarah Di Perbankan Syariah Menurut Prespektif Hukum Positif}

\section{Akad Ijarah di Perbankan Syariah}

Al-Ijarah adalah akad pemindahan hak sewa guna atas barang atau jasa melalui pembayaran upah sewa, tanpa diikuti dengan pemindahan kepemilikan atas barang itu sendiri. ${ }^{7}$ Secara umum akad ini diperbolehkan oleh fuqaha. Hal ini disebabkan meskipun syariat tidak memperbolehkan fixed charge pada modal finansial, namun ia memperbolehkan fixed charge pada modal riil. Hal ini dikarenakan dengan mengubah modal finansial ke dalam aset non finansial penyedia dana sudah melibatkan dirinya dalam suatu risiko. ${ }^{8}$

Secara definitif dalam akad ijārah tidak ada perubahan kepemilikan tetapi hanya perpindahan hak guna saja dari yang menyewakan kepada penyewa. Dalam Hukum Islam ada dua jenis ijārah, yaitu: ${ }^{9}$

a) Ijārah yang berhubungan dengan sewa jasa, yaitu mempekerjakan jasa seseorang dengan upah sebagai imbalan jasa yang disewa. Pihak yang mempekerjakan disebut mustajīr, pihak pekerja disebut ājir dan upah yang dibayarkan disebut ujrah.

b) Ijārah yang berhubungan dengan sewa aset atau properti, yaitu memindahkan hak untuk memakai dari aset atau properti tertentu kepada orang lain dengan imbalan biaya sewa. Bentuk ijārah ini mirip

8 M. Umer Chapra, Sistem Moneter Islam, (Jakarta: Gema Insani, 2000), 118

9 Ascarya, Akad dan Produk Syari" ah, Jakarta: PT. Raja Grafindo Persada, 2007, hlm. 99. 
dengan leasing (sewa) pada bisnis konvensional. Pihak yang menyewa (lessee) disebut mustajīr, pihak yang menyewakan (lessor) disebut mu"jir/muājir dan biaya sewa disebut ujrah.

Ijārah bentuk pertama banyak diterapkan dalam pelayanan jasa perbankan syariah, sementara ijārah bentuk kedua biasa dipakai sebagai bentuk investasi atau pembiayaan di perbankan syariah.

\section{Akad Ijarah Muntahiya Bittamlik (IMBT) di Perbankan Syariah}

Pembiayaan ijārah wa iqtinā" atau ijārah muntahiyah bi at-tamlīk atau akad sewa menyewa yang berakhir dengan kepemilikan merupakan sebuah istilah modern yang tidak asing lagi pada saat ini. Istilah definitifnya tersusun dari dua kata, yaitu; al-Ta"jīr /al-ijārah (sewa) dan alTamlīk (kepemilikan) ${ }^{10}$.

Kata al-tamlīk secara bahasa memiliki arti menjadikan orang lain memiliki sesuatu. Adapun menurut istilah (terminologi) ia tidak keluar dari maknanya secara bahasa. Dan al-tamlīk bisa berupa kepemilikan terhadap benda, kepemilikan terhadap manfaat, bisa dengan ganti atau tidak. Istilah tersebut dapat dibedakakan dalam beberapa katagori berikut ini:

a. Jika kepemilikan terhadap sesuatu terjadi dengan adanya ganti maka ini adalah jual beli.

b. Jika kepemilikan terhadap suatu manfaat dengan adanya ganti maka disebut persewaan.

c. Jika kepemilikan terhadap sesuatu tanpa adanya ganti maka ini adalah hibah/pemberian.

d. Adapun jika kepemilikan terhadap suatu manfaat tanpa adanya ganti maka disebut pinjaman.

Berdasarkan beberapa paparan definisi di atas, maka dapat diambil definisi inti dari ijārah muntahiyah bi al-tamlīk terdiri dari dua kata yaitu kepemilikan suatu manfaat (jasa) berupa barang yang jelas dalam tempo waktu yang jelas, diikuti dengan adanya pemberian kepemilikan suatu barang yang bersifat khusus dengan adanya perpindahan hak, dari hak sewa menjadi hak milik. Hal ini sesuai dengan kaedah fikih:" "mā shahha an yumlika bil al-akhdzi shahha an yumlika bil bay" $i$ ". Maknanya ialah bahwa apa-apa yang dapat diambil manfaatnya, maka dapat pula dijual. Dengan pengecualian, selama barang atau jasa tersebut tidak bertentangan dengan hukum Islam.

Secara rinci, prinsip ujrah (ijārah) dapat dilihat pada uraian di bawah ini:

1. Ijārah Akad sewa menyewa barang antara bank syariah (muājir) dengan penyewa (mustajir). Setelah masa sewa berakhir barang sewaan dikembalikan kepada muājir.

2. Ijārah muntahiyah bi altamlīk (IMBT) Akad sewa menyewa barang antara bank (muājir) dengan penyewa (mustajīr) yang diikuti janji bahwa pada saat yang ditentukan kepemilikan barang sewaan akan berpindah kepada mustajīr.

Merupakan rangkaian dua buah akad, yakni akad al-bai' dan akad ijarah muntahiya bittamlik Al-bai' merupakan akad jual-beli sedangkan IMBT merupakan kombinasi antara sewa-menyewa dan jual beli atau hibah di akhir masa sewa. Dalam ijarah muntahia bittamlik pemindahan hak milik barang terjadi dengan salah satu dari dua cara berikut ini:

a. Pihak yang menyewakan berjanji akan menjual barang yang disewakan tersebut pada masa akhir sewa.

b. Pihak yang menyewakan berjanji akan menghibahkan barang yang disewakan tersebut pada akhir masa sewa.

Menurut Undang-Undang No. 21 Tahun 2008 dan Peraturan Bank Indonesia akad ijarah muntahiya bittamlik" adalah Akad penyediaan dana dalam rangka

11 Muhammad al-Ruky, dalam Mila Sartika \& Hendri Hermawan Adinugraha, Implementasi Ijārah, Ibid. 
memindahkan hak guna atau manfaat dari suatu barang atau jasa berdasarkan transaksi sewa dengan opsi pemindahan kepemilikan barang.

Ijarah Muntahiya Bittamlik adalah sejenis perpaduan antara kontrak jual beli dan sewa lebih tepatnya akad sewa yang diakhiri dengan kepemilikan barang ditangan si penyewa. Sifat permindahan kepemilikan ini pula yang membedakan dengan ijarah biasa.

Pilihan untuk menjual barang diakhir masa sewa biasanya diambil bila kemampuan financial penyewa untuk membayar sewa relatif kecil, akumulasi nilai sewa yang sudah dibayarkan sampai akhir periode sewa belum mencukupi harga beli barang tersebut, bila pihak penyewa ingin memiliki barang tersebut, ia harus membeli barang itu diakhir periode.

\section{Pembiayan Ijarah Muntahiya Bittamlik}

Al-bai ijarah muntahiya bittamlik merupakan rangkaian dua buah akad, yakni akad al-bai dan akad ijarah muntahiya bittamlik. Al-bai merupakan akad jual beli, sedangkan ijarah muntahiya bittamlik merupakna kombinasi antara sewa menyewa (ijarah) dan jaul belia atau hibah diakhir masa sewa. Dalam ijarah muntahiya bittamlik, pemindahan hak milik barang terjadi dengan salah satu dari dua cara berikut:

a) Pihak yang menyewakan berjanji akan menjual barang yang disewakan tersebut pada akhir masa sewa.

b) Pihak yang menyewakan berjanji akan mengubah barang yang disewakan tersebut pada akhir masa sewa.

Implementasi akad ijarah dalam penyaluran dana perbankan syariah dengan menggunakan skema IMBT bertujuan untuk memberikan fasilitas kepada nasabah yang membutuhkan manfaat atas barang dengan sistem sewa, dan pada akhir sewa nasabah mempunyai hak opsi. Adapun objek sewa: properti, alat transportasi, alatalat berat, dan lain-lain. Dalam pembiayaan IMBT Pemilik sewa (Bank) bank wajib menyediakan barang sewa, dan bank juga dapat mewakilkan kepada nasabah untuk menarikan barang yang akan disewa oleh nasabah sedangkan Penyewa (Nasabah). Dokument yang diperlukan oleh bank syariah dalam pembiayaan IMBT adalah surat persetujuan prinsip, Akad Ijarah Muntahiya Bittamlik, Perjanjian pengikatan jaminan, Surat permohonan realisasi ijarah, dan akad pengalihan kepemilikan objek sewa.

Ijarah adalah transaksi sewamenyewa atas suatu barang dan atau upah mengupah atas suatu jasa dalam waktu tertentu melalui pembayaran sewa atau imbalan jasa tanpa diikuti dengan pemindahkan kepemilikan barang. Bank Syariah yang melaksanakan produk ijarah, dapat melakukan dalam bentuk leasing. Akan tetapi pada umumnya, bank syariah lebih banyak menggunakan ijarah muntahiya bit tamlik karena lebih sederhana. Selain itu bank tidak direpotkan untuk mengurus pemelihara asset baik pada saat leasing maupun sesudahnya.

Ijarah Muntahia Bittamlik merupakan rangkain dua buah akad, yakni akad al-bai' dan akad ijarah muntahiya bittamlik. Al-bai' merupakan akad jual-beli sedangkan IMBT merupakan kombinasi antara sewa-menyewa dan jual beli atau hibah di akhir masa sewa.

Dalam konteks perbankan syariah masa kini IMBT diadopsi oleh leasing sehingga praktiknya hampir sama. ${ }^{12}$ Sebab al-bay" wa ijārah muntahiyah bi al-tamlīk merupakan rangkaian dua buah akad, yakni akad al-bay" dan akad ijārah muntahiyah bi al-tamlik. Al-bay" merupakan akad jual

12 Muhammad Syafi'i Antonio, Bank Syariah: Dari Teori ke Praktek, Jakarta: Gema Insani Press, 2001, hlm. 117. 
beli, sedangkan ijārah muntahiyah bi altamlīk merupakan kombinasi sewa menyewa (ijārah) dan jual beli atau hibah di akhir masa sewa. ${ }^{13}$

Pada dasarnya menurut buku Kompilasi Hukum Ekonomi Syariah BAB XI tentang Ijārah Pasal 324 Ayat (2), akad pemindahan kepemilikan pada ijārah muntahiyah bi al-tamlïk hanya dapat dilakukan setelah akad tersebut berakhir. ${ }^{14}$ Akan tetapi dalam perkembangan prakteknya pemindahan hak milik barang terjadi dengan salah satu dari dua cara berikut ini:

a. Pihak yang menyewakan berjanji akan menjual barang yang disewakan tersebut pada akhir masa sewa.

b. Pihak yang menyewakan berjanji akan menghibahkan barang yang disewaakan tersebut pada akhir masa sewa.

Adapun bentuk alih kepemilikan ijārah muntahiyah bi al-tamlīk antara lain:

a. Hibah di akhir periode, yaitu ketika pada akhir periode sewa asset dihibahkan kepada penyewa.

b. Harga yang berlaku pada akhir periode, yaitu ketika pada akhir periode sewa aset dibeli oleh penyewa dengan harga yang berlaku pada saat itu.

c. Harga ekuivalent dalam periode sewa, yaitu ketika membeli aset dalam periode sewa sebelum kontrak sewa berakhir dengan harga ekuivalen.

d. Bertahap selama periode sewa, yaitu ketika alih kepemilikan dilakukan bertahap dengan pembayaran cicilan selama periode sewa.

Adapun ijārah dalam pembiayaan bank syariah untuk pengadaan barang ditambah keuntungan yang disepakati dengan sistem pembayaran sewa tanpa diakhiri dengan pemilikan. ${ }^{15}$ Sedangkan

\footnotetext{
13 Adiwarman A. Karim, Bank Islam Analisi Fiqh dan Keuangan, Jakarta: PT. Raja Grafindo Persada, 2004, hlm. 149.

14 Mahkamah Agung RI, Kompilasi Hukum Ekonomi Syari"ah. Jakarta: Pusdiklat Peradilan Mahkamah Agung RI, 2009, 71

15 Martono, Bank dan Lembaga Keuangan Lain,
}

ijārah muntahiyah bi al-tamlīk dalam perbankan syariah ialah akad sewa menyewa barang antara bank (muājir) dengan penyewa (mustajīr) yang diikuti janji bahwa pada saat yang ditentukan kepemilikan barang sewaan akan berpindah kepada mustajīr. Sedangkan harga sewa dan harga jual disepakati pada awal perjanjian. Hal ini selaras dengan perkataan Ibnu Qudamah mengenai ijarah, yaitu "wa kullu mā jāza tsamanan fi albay' $i$ jāza, iwadhan fi al-ijārah"16

Karim Syah menjelaskan bahwasannya dalam syariah, Bank dianggap pemilik dari barang yang disewakan; oleh karena itu menurut logika, Banklah yang membeli barang dari suplier. Untuk itu diawal Perjanjian IMBT harus ditentukan bahwa Bank Syariah memberi kuasa kepada nasabah untuk membeli barang yang akan menjadi objek ijārah. ${ }^{17}$ Dengan demikian dalam perjanjian IMBT akadnya adalah ijārah dengan wa'ad jual beli/hibah yang akan ditandatangani setelah ijārah berakhir (jika nasabah menghendakinya). Oleh karena itu perlu dilampirkan konsep perjanjian jual beli/hibah; juga dilampirkan konsep kuasa kepada Bank Syariah untuk menjual aset jika pada akhir masa ijārah, nasabah tidak ingin memiliki aset. Kuasa jual diperlukan karena aset sejak masa ijarah sudah dicatatkan atas nama nasabah.

Konsep kuasa jual ditandatangani setelah masa ijārah berakhir". Secara umum, kontrak ijārah bagaimana pun bentuknya, jika objeknya adalah barang yang tidak bergerak, Bank Syariah akan membelinya untuk kepentingan nasabah, yang akan menyerahkan kepada bank suatu imbalan penyewaan dalam jangka waktu yang telah ditentukan, yang cukup untuk menutupi modal pokok, dan bank akan

\footnotetext{
${ }^{16}$ Al-Athrom, Abdurrahman bin Shalih, al-Wasathah alTijāriyyah fí al-Mu" āmalah al-Māliyyah, Riyadh: Dār Isybiyliyā, 1995, hlm. 160

17 Iswahjudi A. Karim, "Pembiayaan Ijarah Muntahiyah Bitamlik”, Paper, KarimSyah Law Firm.Jakarta, 2005, hlm. 5
} 
memperoleh keuntungan dari aktifitas usaha, dan biasanya berakhir dengan perolehan nasabah untuk memiliki barang yang tidak bergerak tersebut. Dan jika berbentuk barang yang bergerak, Bank Syariah juga akan membelinya dan menyewakannya kepada nasabah, di mana nasabah teresebut memiliki hak pilih ketika berakhirnya masa penyewaan, antara memiliki barang tersebut, membuat akad baru ataupun menggugurkannya berdasarkan persyaratan yang telah disepakati. Mengingat bahwasanya kontrak ini tidak diberlakukan pada bank syariah terhadap komoditas yang dapat berubah atau yang cepat habis (barang konsumtif). Oleh karena, pada dasarnya prinsip ijārah sama dengan prinsip murābahah, perbedaannya hanya terletak pada objek transaksinya.

Apabila objek transaksi murābahah adalah barang, sedangkan pada ijarah objek transaksinya adalah barang dan jasa. ${ }^{18}$ Penerapan pembiayaan ijārah dan ijārah muntahiyah bi al-tamlīk (IMBT) di Bank Syariah memiliki kesamaan perlakuan dengan pembiayaan murābahah. Kesamaan ini dapat dilihat dari kesamaan kategori akadnya, yaitu akad jual beli. Perbedaannya hanya pada objek yang diperjual-belikan, pada pembiayaan murābahah objeknya hanya berupa barang sedangkan pada IMBT ialah barang dan jasa. Hal ini juga dibolehkan secara hukum dalam Pasal 19 Undang-Undang Nomor 21 tahun 2008 tentang Perbankan Syariah menyatakan bahwa "kegiatan usaha Bank Umum Syariah salah satunya adalah menyalurkan pembiayaan penyewaan barang bergerak atau tidak bergerak kepada nasabah berdasarkan akad ijārah dan/atau sewa beli dalam bentuk ijārah muntahiyah bi altamlīk (IMBT) atau akad lain yang tidak bertentangan dengan prinsip Syariah".
Akan tetapi pada realitanya ijārah dan/atau IMBT ini jarang diaplikasikan oleh bank syariah, padahal dalam rangka diversifikasi produk pembiayaan, akad ini dipandang perlu untuk dioptimalkan implementasinya.

Pada dasarnya akad ini bisa memberikan keuntungan baik bagi bank syariah ataupun nasabah. Keuntungan yang diperoleh nasabah misalnya ialah penambahan modal untuk meningkatkan investasi, sedangkan keuntungan bagi bank syariah, selain sebagai wujud diversifikasi produk, akad ini dapat mempercepat penyaluran dana dan meningkatkan pola investasi yang baik.

Berdasarkan pembahasan di atas, secara ringkas dapat diuraikankan bahwa landasan hukum ijārah bagi perbankan syariah yaitu Fatwa Dewan Syariah Nasional MUI Nomor 09/DSNMUI/IV2000 tanggal 13 April 2000 tentang Pembiayan Ijarah. Dengan demikian, secara otomatis muamalah ini diperbolehkan oleh syar'i guna kemaslahatan manusia. Dengan alasan, bahwa Nabi pernah bersabda: antum a"lamu bi umūri dunyākum, dan juga para ulama berijtihad atas hal ini dengan apa yang telah disebutkan dari kaidah-kaidah yang terdahulu, yakni "pada asalnya seluruh muamalah itu boleh selama dalam muamalah tersebut tidak bertentangan dengan prinsip syariah, seperti tidak ada riba, gharar, maisir."

Adapun ijārah adalah termasuk salah satu perangkat permodalan dan produk pembiayaan yang penting guna mencapai suatu keuntungan (profit) yang diterapkan oleh perbankan syariah. Metode operasionalnya, bank syariah membeli apa yang diinginkan oleh nasabah yang berupa alat-alat perlengkapan, dan terkadang juga barang yang tidak bergerak (seperti rumah), dan bank syariah menyewakannya kepada

18 Muhammad, Manajemen Bank Syariah, Yogyakarta: UPP STIM YKPN, 2011, hlm. 99. 
mereka, dengan harga yang telah disepakati.

Biasanya, pengembaliannya dengan cara angsuran tiap bulan atau dengan cara berkala sesuai dengan kesepakatan pada akad. Kemudian bank syariah memberikan pilihan pada saat berakhirnya kontrak, untuk memiliki barang yang disewa dengan cara membelinya dari bank (ijārah muntahiyah bi al-tamlīk), atau dengan menyerahkannya kembali kepada bank (ijārah).

Pada prinsipnya, bank syari'ah adalah sama dengan perbankan konvensional, yaitu sebagai instrumen intermediasi yang menerima dana dari nasabah yang surplus dana (dalam bentuk penghimpunan dana) dan menyalurkannya kepada pihak yang membutuhkan (dalam bentuk produk penyaluran dana). Sehingga produk yang disediakan oleh bank-bank konvensional, baik itu produk penghimpunan dana (funding) maupun produk pembiayaan, pada dasarnya dapat pula disediakan oleh bank syari'ah. ${ }^{19}$

Dalam menjalankan produk KPR, bank syari'ah memadukan dan menggali skim-skim transaksi yang dibolehkan dalam Islam dengan operasional KPR perbankan konvensional. Adapun salah satu skim yang digunakan oleh perbankan syari'ah di Indonesia dalam menjalankan produk pembiayaan KPR adalah skim ijarah muntahiya bi tamlik (IMBT).

Berdasarkan skim ijarah ini, bank syari'ah menyewakan rumah, sebagai objek akad, kepada nasabah. Meskipun pada prinsipnya tidak terjadi pemindahan kepemilikan (hanya pemanfaatan rumah), tetapi pada akhir masa sewa bank dapat menjual atau menghibahkan rumah yang disewakannya kepada nasabah. Berikut aplikasi Pembiayaan IMBT: ${ }^{\mathbf{2 0}}$

a. Bank Syariah dan Developer mengadakan Perjanjian Kerjasama (MOU) pemilikan rumah. Bank

19 Helmi Haris, "Pembiayaan Kepemilikan Rumah (Sebuah Inovasi Pembiayaan Perbankan Syari'ah)" La Riba Jurnal Ekonomi Islam, Vol. I, No. 1, Juli 2007
Syariah akan menyediakan fasilitas pembiayaan pemilikan rumah bagi calon pembeli rumah Developer.

b. Pembeli atau calon nasabah bermaksud membeli rumah di lokasi milik Developer dan mengajukan Pembiayaan Pemilikan Rumah kepada Bank Syariah. Calon Nasabah melengkapi persyaratan permohonan pembiayaan sesuai kriteria yang dipersyaratkan. Jika persyaratan lengkap, Bank Syariah selanjutnya melakukan analisa kelayakan pembiayaan terhadap calon nasabah.

c. Jika calon nasabah layak dibiayai, maka Bank Syariah akan mengeluarkan Surat Persetujuan kepada calon nasabah (surat penawaran). Calon Nasabah melakukan negosiasi dengan Bank. Jika terjadi kesepakatan, calon nasabah menandatangani surat penawaran dan berjanji ( $\left.w a^{\prime} a d\right)$ untuk melakukan transaksi IMBT dengan Bank Syariah.

d. Bank Syariah melakukan transaksi rumah (berdasarkan Perjanjian Kerjasama) dengan Developer sesuai spesifikasi rumah yang diminta oleh calon nasabah, secara prinsip (fiqih) rumah menjadi milik Bank Syariah (dokumentasi rumah dibuat atas nama Nasabah)

e. Nasabah dan Bank Syariah melakukan Perjanjian Pembiayaan Pemilikan Rumah Berdasarkan Prinsip IMBT dengan janji (wa"ad) dari Bank Syariah untuk melepaskan kepentingannya atas rumah (akad fiqih hibah) setelah seluruh kewajiban nasabah lunas.

f. Developer sebagai wakil Bank (berdasarkan Perjanjian Kerjasama) menyerahkan rumah kepada nasabah (Nasabah mendapatkan manfaat rumah selama masa IMBT).

g. Nasabah membayar kewajiban ke Bank Syariah sesuai jadwal yang disepakati.

20 Fathurrahman Djamil," Satuan Acara Pengajaran Mata Kuliah Fiqh Muamalah Dalam Keuangan Dan Perbankan Islam" (2011) 
h. Sesuai kesepakatan di awal akad, Bank Syariah dan Nasabah sepakat untuk melakukan review terhadap jumlah kewajiban Nasabah pada setiap periode yang ditentukan.

i. Di akhir masa IMBT, Bank Syariah merealisasikan janjinya (wa'ad) dengan melepaskan kepentingan atas rumah dan menyerahkan rumah kepada nasabah (akad fiqih hibah) setelah seluruh kewajiban Nasabah dilunasi.

Secara umum, aplikasi perbankan dapat digambarkan skema berikut: ${ }^{21} \mathrm{Al}$ Ijārah al-Muntahiya bit al-Tamlik (IMBT) merupakan salah satu alternatif skim syariah untuk memfasilitasi pembiayaan jangka menengah dan jangka panjang yang sesuai dengan jenis usaha nasabah sekaligus mengamankan kepentingan bank. Dibandingkan dengan akad mudharabah, akad IMBT ini lebih fleksibel dan kompetitif bagi nasabah dalam penetapan harga sewa, walaupun ada beberapa risiko yang mungkin terjadi yang harus diantisipasi seperti risiko default yaitu nasabah tidak membayar cicilan dengan sengaja, aset ijarah rusak sehingga menyebabkan biaya pemeliharaan bertambah, terutama bila disebutkan dalam kontrak bahwa pemeliharaan harus dilakukan oleh si pemberi sewa (muajjir), dan nasabah berhenti di tengah kontrak dan tidak mau membeli aset tersebut. Akibatnya bank harus menghitung kembali keuntungan dan mengembalikan sebagian kepada nasabah.

\section{PENUTUP}

\section{A. Kesimpulan}

1. Permasalahan hukum pengaturan akad pembiayaan ijarah pada perbankan syariah menurut hukum positif adalah pengaturan akad pembiayaan ijarah belum diatur secara detail sehingga belum dipahami oleh pengelola dan nasabah perbankan syariah.

2. Model akad ijarah di perbankan syariah menurut prespektif hukum positif adalah model akad pembiayaan dan pelayanan jasa diantaranya akad pembiayaan sewa menyewa, sewa beli dengan opsi peralihan kepemilikan (ijarah muntahiyah bittamlik), dan akad multijasa, serta akad pelayanan jasa perbankan syariah seperti save deposit box.

\section{B. Saran}

1. Pemerintah perlu segera menerbitkan peraturan pelaksanaan terhadap Undang-Undang Nomor 21 Tahun 2008 tentang Perbankan Syariah khususnya yang berkaitan dengan akad ijarah.

2. Majelis Ulama dan para ahli Hukum Islam perlu segera menyusun panduan akad ijarah sebagai pedoman bagi perbankan syari'ah dalam operasionalnya.

\section{DAFTAR PUSTAKA}

Ascarya. 2011. Akad dan Produk Bank Syariah, Edisi I, Cetakan ke-3, Rajawali PT. Raja Grafindo Persada, Jakarta.

Ali, Muhammad Daud, 1998, Hukum Islam, Pengantar Ilmu Hukum dan Tata Hukum Islam Indonesia, Radja Grafindo Persada, Jakarta.

Antonio, Muhammad Syafi'i, Bank Syariah: Dari Teori ke Praktek, Jakarta: Gema Insani Press, 2001.

${ }^{21}$ Muhammad Syafi'i Antonio, Bank Syariah Dari Teori ke Praktek, (Jakarta: Gema Insani, 2001), 119 
Dewi, Gemala, 2004, Aspek-Aspek Hukum Dalam Perbankan dan Perasuransian Syari'ah Di Indonesia, Kencana, Jakarta.

Ghufron, Sofiniyah. 2005. Briefcase Book Edukasi Profesional Syariah, Konsep dan Implementasi Bank Syariah, Renaisan, Jakarta.

Ichtianto, 1991, Pengembangan Teori Berlakunya Hukum Islam di Indonesia" dalam Tjun Suryaman (ed), Hukum Islam di Indonesia: Perkembangan dan Pembentukan, Rosdakarya, Bandung.

Karim, Adiwarman A, Bank Islam Analisi Fiqh dan Keuangan, Jakarta: PT. Raja Grafindo Persada, 2004.

Mahmud Marzuki, Peter, Penelitian Hukum, Kencana, Jakarta, 2004

Muchsin, 2004, Masa Depan Hukum Islam di Indonesia, STIH IBLAM, Jakarta.

Martono, Bank dan Lembaga Keuangan Lain, Yogyakarta: Ekonisia, 2002.

Muhammad, Manajemen Bank Syariah, Yogyakarta: UPP STIM YKPN, 2011.

Muhayatsyah, Ali, "Ijarah dan Ijarah Muntahiya Bittamlik (IMBT) dalam Instrumen Keuangan Syariah", Paper, Yogyakarta: UIN Sunan Kalijaga, 2012.

Nazir, Habib dan Muh. Hasan, Ensiklopedi Ekonomi dan Perbankan Syari"ah. Bandung: Kaki Langit, 2004.

P. Usanti dan Abd. Shomad. 2013.Transaksi Bank Syariah, Cetakan I, PT. Bumi Aksara, Jakarta.

Remy, Sutan Sjahdeini. 2007. Perbankan Islam, Cetakan ke-3, PT. Pustaka Utama Grafiti, Jakarta.

Salim HS dan Erlies Septiana Nurbani. 2013. Penerapan Teori Hukum Pada Penelitian Tesis dan Disertasi, Cetakan I, PT. Raja Grafindo Persada, Jakarta.

Soerjono Soekanto dan Sri Mamudji, 1995, Penelitian Hukum Normatif,
RadjaGrafindo Persada, Jakarta, 1995.

Sabiq, Sayyid, Fiqh al-Sunnah. Jilid 3, Beirut: Dār al-Kitāb al-Araby, 1983.

Tim Penulis Dewan Syari'ah Nasional (DSN) MUI, Himpunan Fatwa Dewan Syari" ah Nasional, Jakarta: PT. Intermasa, 2003.

Umam, Khotibul. 2016. Perbankan Syariah, Dasar-dasar dan Dinamika Perkembangannya di Indonesia, Edisi I, Cetakan I, PT. Raja Grafindo Persada. Jakarta.

Usman, Rahmadi. 2009. Produk dan Akad Perbankan Syariah di Indonesia Implementasi dan Aspek Hukum, Cetakan I, PT. Citra Aditya Bakti, Bandung.

Yuliana, Indah, Investasi Produk Keuangan Syariah, Malang: UIN-MALIKI Press, 2010.

\section{Peraturan Perundang-Undangan}

Undang-Undang Nomor 21 Tahun 2008 Tentang Perbankan Syariah, LN Republik Indonesia Tahun 2008 Nomor 94, TLN Republik Indonesia Nomor 4867

Fatwa Dewan Syariah Nasional Nomor 09/DSN-MUI/IV/2000 tentang Pembiayaan Ijarah.

Fatwa Dewan Syariah Nasional Nomor 44/DSN-MUI/VIII/2004 tentang Pembiayaan Multijasa

Peraturan Bank Indonesia Nomor 7/46/PBI/2005 tentang Akad Penghimpun dan Penyalur Dana Bagi Yang Melaksanakan Kegiatan Usaha Berdasarkan Prinsip Syariah.

Peraturan Bank Indonesia Nomor 9/19/PBI/2007 tentang Pelaksanaan Prinsip Syariah Dalam Kegiatan Usaha Penghimpun Dana dan Penyalur Dana Serta Pelayanan Jasa Bank Syariah.

Surat Edaran Bank Indonesia Nomor 10/14/Dpbs tanggal 17 Maret 2008 tentang Pelaksanaan Prinsip Syariah 
dalam Kegiatan Penghimpun Dana dan Penyaluran Dana serta Pelayanan Jasa Bank Syariah.

Peraturan Mahkamah Agung, Nomor 2 Tahun 2008 tentang Kompilasi Hukum Ekonomi Syari"ah. Jakarta: Pusdiklat Peradilan Mahkamah Agung RI, 2009. 